\title{
1 Manganese in the Upper Severn mid-Wales
}

2

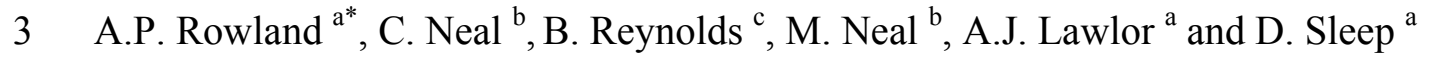
4

$5 \quad{ }^{a}$ Centre for Ecology and Hydrology, Lancaster. Lancaster Environment Centre, Library

6 Avenue, Bailrigg, Lancaster, LA1 4AP, UK.

$7 \quad{ }^{\mathrm{b}}$ Centre for Ecology and Hydrology, Crowmarsh Gifford, Wallingford, OXON, OX10

8 8BB, UK

$9{ }^{\mathrm{c}}$ Centre for Ecology and Hydrology, Environment Centre Wales, Deiniol Road, Bangor

10 Gwynedd, LL57 2UW, UK

\section{Abstract}

14 The concentrations of manganese (Mn) in the Upper River Severn (the Plynlimon

15 catchments) are examined in relation to rainfall, cloud water, throughfall, stemflow and

16 stream water concentrations where there is over 20 years of monitoring data available.

17 Manganese concentrations are particularly low in rainfall and cloud water, with

18 maximum concentrations occurring under low volumes of catch due to atmospheric

19 "washout" of contaminants and dry deposition. There is strong Mn enrichment in

20 throughfall and stemflow and this is probably linked to cycling through the vegetation.

21 Manganese in the streams and groundwaters are primarily supplied from within-

22 catchment sources. The highest concentrations occur within the tree canopy probably due

23 to element cycling and in groundwaters due to mobilisation from the rock. Manganese

24 concentrations are at their lowest during spring and summer following long dry spells,

25 with rapid increases following subsequent rain. There is no clear long-term trend in Mn

26 concentration in the streams although there are increases in Mn concentrations for years

27 when there is extensive felling of spruce plantation forest and in 1995 following a more

28 extensive dry period. New high resolution monitoring picks up the effects of the rising

29 limb of the hydrograph when concentrations rapidly increase, diurnal patterns during 
30 summer low-flow periods and contrasting dynamics between moorland and forested

31 catchments.

\section{Impact Statement}

33 Manganese release from catchments can pose water quality issues for river systems

34 especially within acidic and acid sensitive upland areas or from disturbance from forestry

35 clearance. During a precipitation event, $\mathrm{Mn}$ is displaced from the soils into the streams

36 and then subsequent events have a more limited impact on stream concentrations. In

37 contrast in drought periods when the stream is at base flow concentrations decline and

38 diurnal cycling is observed. Long-term and high resolution monitoring shows features

39 influenced by a combination of changes driven by factors such as climatic variation and

40 land use change with complex within-catchment, hyperheic-river and within-river

41 processing that requires further evaluation.

\section{$42 \quad$ 1. Introduction}

44 The UK uplands are of strategic environmental importance, with the headwaters of many

45 major river systems providing a major source of potable, industrial and agricultural water

46 supplies and often constitute areas of outstanding natural beauty with high amenity /

47 ecological status. Despite this, they have been and continue to be susceptible to the

48 deposition of acidic oxides from industrial emissions ${ }^{1}$ and there is also an issue of

49 forestry rotation cycles following the introduction of conifer plantations onto acidic and

50 acid sensitive moorland during the first half of the twentieth century. ${ }^{2,3}$

52 Although the main focus on UK upland water quality has been on those components

53 directly linked to acidification and forestry rotation cycles, such as $\mathrm{pH}$, inorganic

54 aluminium and strong acid anions (chloride, sulphate and nitrate), there are other issues

55 of importance. In this paper we deal with manganese (Mn). Concentrations can be

56 relatively high in UK upland rivers and the levels encountered can be of both ecological

57 and water potability significance. ${ }^{4-8}$ Concentrations exceeding the guideline value for 
58 public supplies of $50 \mu \mathrm{g} \mathrm{L}^{-19}$, for example arising from soil disturbance and erosion

59 from forest operations ${ }^{10}$, may affect the taste and reduce the water pressure and flow in

60 the supply pipes. ${ }^{11}$

61

62 Manganese is the twelfth most abundant element and, after iron and titanium, the third

63 most abundant transition element in the earth's crust averaging $0.106 \%{ }^{12}$ Despite this,

64 Mn concentrations are moderately low in surface waters (typically less than $1 \mathrm{mg} \mathrm{L}^{-1}$ )

65 with the ratio of dissolved concentration river water and seawater to the crustal average

66 being around two orders of magnitude lower than ions such as sodium and chloride but

67 two orders of magnitude higher than easily hydrolysable trivalent metals such as iron and

68 aluminium. ${ }^{13}$ Manganese has a wide range of oxidation states $(-3$ to +7$)$ but in nature it

69 primarily occurs in solution and in mineral forms in oxidation states of Mn II and Mn IV,

70 the latter having such a high surface charge density that in this form Mn predominates as

71 low solubility oxides and oxy-hydroxides. Under reducing conditions, Mn II is mobilised

72 but it is lost from the water column in well-oxygenated surface environment where

73 oxidation occurs leading to a much lower solubility.

75 In this paper, Mn concentrations are described for a key experimental research area in the

76 UK uplands (the Plynlimon catchments of mid-Wales) where there have been extensive

77 water quality monitoring of rainfall, mist, stream and ground waters over 27 years. ${ }^{14,15}$

78 The paper also presents the results of a new high resolution monitoring programme that

79 indicates remarkable dynamics for Mn concentrations in streams draining moorland and

80 harvested forest. The aims of the study are to examine the biogeochemical cycling of Mn,

81 to describe the processes that occur during storm events and the diurnal changes in stream

82 concentrations during low flow periods in the summer. Within the study new data on the

83 short-term dynamics are brought to the fore based on a new high resolution study of

84 rainfall and runoff within one of the main tributaries of the upper Severn, the Afon

85 Hafren. ${ }^{16}$ The hypothesis tested is that by undertaking long-term and high intensity

86 monitoring of Mn reveals new features that add to or challenges our understanding of

87 hydrogeochemical functioning. ${ }^{17}$ 


\section{Experimental}

\section{Study area}

91

92 The study area comprises the headwaters of the River Severn (catchment c. $8 \mathrm{~km}^{2}$ ). ${ }^{18}$

93 Here (Figure 1), the Upper River Severn drains a hill top plateau region dominated by

94 acid moorland and the Hafren Forest in the lower half of the catchment. The Upper

95 Severn comprises two main tributaries, the Afon Hafren and the Afon Hore, together with

96 the Nant Tanllwyth that joins the Afon Hafren near to its confluence with the Afon Hore.

97 The soils in the area are a mixture of upland acid soil types dominated by peaty podzol

98 with some peaty gley and deep peat in the moorland plateau area. The bedrock is

99 fractured Lower Palaeozoic mudstones, shales and grits. The Hafren Forest mainly

100 comprises of Sitka spruce with some Norway spruce, larch and lodgepole pine, planted in

101 various phases from the mid 1940s through to the late 1960s. Both the lower parts of the

102 Hafren and the Hore are within the Hafren forest, while the Tanllwyth catchment is fully

103 within the forest. However, during the study there has been thinning of the forest in

104 places and complete deforestation with replanting in others (details are provided in Table

105 1). The water quality of the Upper Severn is variable, with baseflow waters of good

106 quality (calcium bicarbonate type) and more acidic and aluminium bearing water of much

107 poorer quality occurring under stormflow conditions. The general water quality

108 functioning of the area is provided by Neal et al., ${ }^{14,19}$, the groundwater chemistry ${ }^{15}$ and

109 broader aspects are covered in a special issue of Hydrology and Earth System Sciences. ${ }^{20}$

110 With regards to rainfall and stream flows, summary information is provided elsewhere ${ }^{21}$

111 as is information on groundwater levels ${ }^{15}$. Details of the high resolution water quality

112 study are covered elsewhere. ${ }^{16}$

113

\section{Sample collection and chemical analysis}


116 For this study, information is drawn from monitoring programmes of rainfall, cloud

117 water, throughfall, stemflow, stream water and groundwater covering time frames from

118 one to almost thirty years (Table 1). Samples were mainly collected on a weekly basis ${ }^{14}$

119 and additionally a 7 hourly monitoring programme in the case of rainfall and the Upper

120 and Lower Hafren for 2007-2008. ${ }^{16}$ Briefly, the samples of rainfall (bulk deposition) and

121 cloud water (occult deposition) were collected using open and passive lidded "harp type"

122 collectors respectively at the Carreg Wen meteorological site $\left(52^{\circ} 29^{\prime} \mathrm{N}, 3^{\circ} 43^{\prime} \mathrm{W}\right)$

123 approximately $0.5 \mathrm{~km}$ to the south of the Upper Hafren stream flow gauging structure at

124 an altitude of $580 \mathrm{~m} .^{22}$ The throughfall was collected using 4 trough collectors while

125 stemflow was collected from 4 trees using diagonally slanted tubing fixed to the bark that

126 transferred water to a collector at the base of each tree. ${ }^{23}$ The samples for rainfall, cloud

127 water, throughfall and stemflow were time integrated ones, while for the streams and

128 groundwaters, instantaneous grab samples were collected. At each of the stream sampling

129 sites, an instantaneous sample of stream water was collected every seven hours using

130 Xian 1000 portable automatic samplers, each fitted with a carousel of twenty four $500 \mathrm{ml}$

131 high density polythene bottles and housed in enclosures on the stream bank. ${ }^{16}$ The

132 samplers operate on a pressure / vacuum principle drawing water into a silicone coated

133 glass bottle before dispensing it into a $500 \mathrm{ml}$ sample bottle. The waters were filtered

134 within 24 hours on return to the laboratories for rainfall, cloud water, throughfall and

135 stemflow, while the stream and groundwater samples were filtered in the field. Filtration

136 was undertaken under vacuum using $0.45 \mu \mathrm{m}$ cellulose acetate circles apart from the 7

137 hourly monitoring samples when pressure filtration was used. In all cases, the filtration

138 equipment was thoroughly cleaned before use and the filters / filtration equipment bottles

139 were washed with several aliquots of sample before the sample for analysis was

140 collected. All the sample bottles were pre-washed with $10 \% \mathrm{HCl}(\mathrm{v} / \mathrm{v})$ acid-washed

141 polyethylene bottles.

142

143 The samples were stored, at $4^{\circ} \mathrm{C}$ in the dark, in acid washed polypropylene bottles,

144 acidified to $1 \% \mathrm{v} / \mathrm{v}$ with high purity concentrated nitric acid within one day of sampling

145 to avoid sample deterioration. Mn concentrations were determined using inductively

146 coupled plasma emission spectrometry (Perkin Elmer DV 3400 ICP-OES) ${ }^{14}$ up to 1997 , 
147 and by inductively coupled plasma mass spectrometry (Perkin Elmer DRC II ICP-MS)

148 from 1997 onwards. All analysis from the samples collected from 1997 onwards was

149 conducted according to ISO 17025 and accredited by the United Kingdom Accreditation

150 Service. Calibration standards were cross-checked against certified reference material;

151 for example the National Research Council Canada River Water SLRS-4 Mn bias was

152 2\% in May 2007. To minimise the likelihood of bias between laboratories, both

153 laboratories participated in an external proficiency testing scheme (Aquacheck); for

154 example the average bias of 5 PT samples in 2007 and 2008 was $-5 \%$ with a range

155 between -2 and $-7 \%$. Analysis involved three replicate measurements and approximately

$15610 \%$ of each analytical batch contained internal quality control samples as a means of

157 validating each measurement. For the ICP-OES, check standards were used to correct for

158 instrument drift, and if the standards run as samples differed from the true values by more

159 than 5\% then the analysis was repeated. For ICP-MS, an internal standard of gallium was

160 used to correct each sample for instrumental drift. The lowest quotable value for Mn was

$1610.2 \mu \mathrm{g} \mathrm{L}^{-1}$ for ICP-OES and $0.02 \mu \mathrm{g} \mathrm{L}^{-1}$ for ICP-MS (calculated on $4 * \mathrm{~s} \mathrm{n}=10$ blank

162 determinations). However, data without the detection limit filter applied is used in the

163 statistical analysis for this paper.

\section{Results and Discussion}

169 The results from the weekly samplings collected over the last 30 years are summarized in

170 Table 2 together with ancillary information for catchments nearby (Table 3) while Mn

171 concentration time series are shown in Figure 2 for the main long-term term monitoring

172 sites on the Hafren, Hore and Tanllwyth.

$174 \quad 3.1$ Atmospheric inputs and leaching from forests 
176 Manganese concentrations are highly variable with lowest average concentrations

177 occurring in rainfall (average, median and standard deviation 2, 1 and $5 \mu \mathrm{g} \mathrm{L}^{-1}$,

178 respectively). The variations in Mn concentrations across the Upper Severn fit well with

179 previous studies. For example, Mn concentrations in the rainfall and cloud water are

180 relatively low and the highest concentrations occur at low volumes of catch due to

181 atmospheric scavenging processes and there can be a significant deposition flux related to

182 the cloud water input. ${ }^{22}$ For the Upper sites streams in the moorland, the contributions to

183 the streams are low and arise from the precipitation and surface soil leaching. Highest

184 average and median concentrations occur in throughfall and stemflow (723 / 571 and

$1851414 / 949 \mu \mathrm{g} \mathrm{L}^{-1}$, respectively), arising from both the wet and occult deposition,

186 resulting in enhanced Mn deposition in the forested catchments of the Lower Hafren and

187 Lower Hore. Within the throughfall and stemflow there are high concentrations of Mn

188 and this fits well with previous observations where there can be substantial leaching from

189 the foliage. ${ }^{24-26}$

190

$191 \quad 3.2$ Streams (main, intermediate and small)

193 For the main streams, Mn concentrations are similar in terms of average, median and 194 range (Table 2). Further, unlike rainfall, the average values are similar to the median and 195 for the remainder of this section, only average values are provided to avoid duplication.

196 For example, for the Upper and Lower Hafren and Hore, the average Mn concentrations 197 range between 20 and $35 \mu \mathrm{g} \mathrm{L}^{-1}$ with Mn concentrations higher at the lower sites 198 attributable to the contribution of the soil water and canopy leachates from the conifer 199 plantations. For the 'intermediate stream' of the Tanllwyth, the average Mn concentration

$200\left(89 \mu \mathrm{g} \mathrm{L}^{-1}\right)$ is around three times higher than the other streams and similar to arsenic ${ }^{27}$. 201 The small streams show a variable range in average ( 8 to $70 \mu \mathrm{g} \mathrm{L}{ }^{-1}$ ) although there is no 202 clear separation between the drainage for the podzol and gley soils. We suspect that there 203 is an influence of soil type but we may not be comparing similar water types (see below) 204 and in general averages / medians are similar while standard deviations are fairly high.

205 For the streams, mean and maximum Mn concentrations are generally lower in headwater 206 streams that rise in the Drosgol and Brynglas Formations (Upper Hafren, Upper Hore) 
compared to the other headwater streams. As previously noted, Mn mobilisation seems linked to soil horizons with a mixture of organic and inorganic materials. ${ }^{6}$ However the data for the small streams, which are notionally all on the same mudstone bedrock (Glaslyn Formation), show that these broad relationships are modified and confounded by the influence of soil type and hydrology as well as factors such as drying / wetting cycles. ${ }^{6}$ Even at the relatively small scale of the Upper Severn catchment $\left(\right.$ c. $\left.8 \mathrm{~km}^{2}\right)$ it is difficult to explain the relatively large variability in stream and groundwater $\mathrm{Mn}$ concentrations without detailed analysis of hydrological flow paths in relation to soil type and land cover.

However, within the main streams, the lowest Mn concentrations occur at the lowest of flows especially after extensive periods of drought. This decline at very low flows (Figure 2) probably indicates a removal of Mn from the water column under baseflow conditions as opposed to the increased contribution of groundwater. If groundwaters dominated during baseflow conditions the stream Mn concentrations would be expected to be maximal as groundwater concentrations are much higher than stream averages (Table 2). On wetting up, Mn concentrations rapidly increase in concentrations to nondrought levels and for some streams there is a marked decline in concentration with increasing flow from moderate to high flows (Figure 3 ) and probably reflects a dilution term following storm-break, when removal of $\mathrm{Mn}$ from the water column is small. As such the relationship between $\mathrm{Mn}$ and flow shows both linear and inverse relationships that are also indicated by linear regression (Table 4).

Although we focus on the upper River Severn, there is companion Mn data for the upper River Wye. For this area there are three monitoring points: the Afon Gwy (acid moorland), the Afon Cyff (agriculturally improved, limed, grassland) and the Nant Iago (moorland contaminated by a derelict lead-zinc mine with spoil waste). ${ }^{28} \mathrm{Mn}$ concentration averages are 17, 24 and $33 \mu \mathrm{g} \mathrm{L}^{-1}$ for the Gwy, Cyff and Iago, respectively. In a companion study of conifer forest on brown earth soils average Mn concentrations in runoff averaged 7 and $10 \mu \mathrm{g} \mathrm{L}^{-1}$ for two sites. ${ }^{29}$ These values clearly are similar to those for the Upper Severn. 


\subsection{Groundwaters and the correspondence with the streams}

241 The groundwaters (Table 2) also exhibit a wide range in average and median $\mathrm{Mn}$

242 concentrations $\left(8 / 2\right.$ to $\left.332 / 217 \mu \mathrm{g} \mathrm{L}^{-1}\right)$. As with the streams, the average and median

243 concentrations are similar and for brevity only averages are described here. In general the

244 Mn concentrations in groundwater are about three times higher than within the streams

245 (averages 115 and $35 \mu \mathrm{g} \mathrm{L}^{-1}$, respectively). For Plynlimon, average groundwater

246 concentrations exceed the national drinking water limit of $50 \mu \mathrm{g} \mathrm{L}^{-1}$. For the 16 boreholes,

247 the majority (81\%) show elevated average concentrations above the drinking water limit

248 with maximum measured values up to thirteen times this threshold limit. Only in one of

249 these sampling points (Quarry) was the average value $\left(2 \mu \mathrm{g} \mathrm{L}^{-1}\right)$ well below this limit.

250 The concentrations in this catchment are well above the median of $13 \mu \mathrm{g} \mathrm{L}^{-1}$ for Scottish

251 groundwaters. ${ }^{9}$ With respect to the Plynlimon streams, average concentrations for the

252 Upper and Lower Hafren and Hore as well as the remaining small streams are below the

$25350 \mu \mathrm{g} \mathrm{L}^{-1}$ threshold, with only occasional exceedance.

254

255 Manganese in the streams and groundwaters are mainly derived from the catchment

256 (typically around 90 to $95 \%$ ) as shown for the Plynlimon catchments with previous mass-

257 balance studies ${ }^{14,30}$ and the highest concentrations occur within the groundwaters where

258 residence times will be high. Some of the broad variations in Mn concentrations amongst

259 the streams and groundwater can probably be accounted for by variations in bedrock Mn.

260 Concentrations of $\mathrm{Mn}$ in four of the bedrock units present at Plynlimon vary by an order

261 of magnitude (Table 5) from $3200 \mathrm{mg} \mathrm{kg}^{-1}$ in the Silurian Devils Bridge Formation Series

262 to $218 \mathrm{mg} \mathrm{kg}^{-1}$ in the Drosgol Formation of Ordovician age. ${ }^{31,32}$ Thus, groundwater in

263 boreholes intercepting the Drosgol Formation (US1-US3) generally has lower Mn

264 concentrations relative to those intersecting other formations. However this broad

265 simplification is confounded by the modifying influence of catchment hydrological

266 pathways on the chemistry of the water measured in the boreholes. The boreholes were

267 not screened to sample water from a specific depth in the soil, drift or bedrock. Thus

268 some of the shallower holes intercept soil through-flow whilst deeper holes sample "true" 
269 groundwater: c.f. an earlier presentation on groundwaters at Plynlimon. ${ }^{15}$ There is a

270 strong vertical gradient in soil total Mn concentrations as shown by the example soil

271 profiles under acid grassland in the Wye catchment (Table 6). ${ }^{33}$ Thus for a given

272 geology, lower Mn concentrations might be anticipated in those boreholes which sample

273 soil water compared to those intercepting groundwater in the bedrock. The groundwaters

274 have variable depth with the shallowest being for VB1, LS1, LS2, LS3 and US1 (depths

275 averaging less than $2 \mathrm{~m}$ ), while the deepest being for US2 and US3 (averaging around 11

$276 \mathrm{~m}$ ): the other sites have average depths typically around 4 to $8 \mathrm{~m}$. Mn concentrations do

277 not exhibit clear relationships with depth in terms of individual sites or averages across

278 sites and clearly the $\mathrm{Mn}$ inputs to the groundwater across the area are variable and the

279 underlying processes not easy to pin down. Nonetheless, the highest concentrations in the

280 groundwater are associated with the gley catchments, but there also seems to be high

281 concentrations associated with one site in gravels near to the river (VB1). The Mn

282 mobilisation may well be linked to reducing conditions but other factors also come into

283 play. ${ }^{9}$ Further, with reducing conditions Fe is also mobilised, but Mn is only weakly

284 correlated with Fe. However, we have noted that in the groundwaters, green $\mathrm{Fe}(\mathrm{OH})_{2}$

285 flocks form within the groundwaters sampled within the gley and similar precipitates

286 form within the streams at seepage points and the flocks turn brown on oxidation in the

287 stream. As such, the linkage between Mn and Fe may be weakened by differences in

288 oxidation and precipitation kinetics. In fact, the only strong relationship with $\mathrm{Mn}$ is cobalt

289 (both in the groundwater and stream) and this may well reflect similar hydrochemical

290 characteristics.

$292 \quad 3.4$ The issues of Mn mobility in relation to conifer harvesting / replanting and

293 climatic effects

294

295 Clear felling of the forest results in disturbance of the forest soils and this seems to have

296 released Mn within the soils to be flushed to the river during periods of high flow when

297 the catchment wets up. At Plynlimon, stem-only harvesting was practised and residual

298 material (including stumps) was left on the catchment. The majority of the felled areas

299 were replanted with Sitka spruce within two years of harvesting, although some high 
300 altitude ground above the source of the Hore has been left unplanted and will be allowed

301 to revert to open moorland. The data shows an increase in Mn concentration followed by

302 a decline within a few years. For example, for the Lower Hore where about a half of the

303 catchment was felled over a four year period from 1985 to 1988, Mn concentrations

304 increased from around $30 \mu \mathrm{g} \mathrm{L}^{-1}$ to around $40 \mu \mathrm{g} \mathrm{L}^{-1}$ (Figure 2), while for small

305 South2Hore stream, felling over a few months in 1989 led to an increase from around 100

$306 \mu \mathrm{g} \mathrm{L} \mathrm{L}^{-1}$ to around $150 \mu \mathrm{g} \mathrm{L}^{-1}$ with decline over the next few years to levels about a $60 \%$

307 that of pre-fell (Figure 2, Table 7). Clearly, the disruption of the soils at times of fell and /

308 or the release of $\mathrm{Mn}$ from forest debris ${ }^{5}$ led to $\mathrm{Mn}$ release to the streams. Regarding long

309 term changes in Mn concentration, linear regression indicates that there are no significant

310 trends apart from the situation where initial felling enhanced Mn concentrations as

311 followed by subsequent decline. Other than a felling effect, perhaps the major changes

312 observed link to climate impacts as stream concentrations are strongly related to monthly

313 rainfall amounts $(\mathrm{r}=0.888, \mathrm{p}<0.0001)$ with the greatest stream concentration associated

314 with the higher rainfall between from October to February. However, on an annual basis,

315 the average stream concentrations are not correlated with annual rainfall amount. For the

316 Lower Hafren average Mn concentrations appear to have declined in the last decade

317 although the change is not uniform (Figure 2). Indeed, care has to be taken in examining

318 trends as there are also the impacts of felling practice to consider. For the upper Hafren,

319 where there has been no land disturbance as the system is simply moorland, there are no

320 clear trends at all and it may well be that any trends must be reviewed in relation to land

321 management and climatic factors.

\section{$324 \quad 3.5$ Mn cycling during storm events and drought periods}

326 The 7 hour data for the Upper Hafren (where there is the longest data run) shows the

327 highly dynamic nature of Mn concentrations within the stream (Figure 4). Indeed,

328 following Neal et al. ${ }^{16}$, the influence of reducing sampling frequency can be clearly

329 observed (Figure 4). The degree of variability is as dynamic as that for flow but over a

330 narrower range of values. Looking over a smaller time period (Figure 5), the 7 hourly 
monitoring indicates that the initial rise in Mn concentration, following drought break on day 262, occurs rapidly (within a day) and is linked to the rising limb of the hydrograph. Subsequently Mn concentrations gradually decline in line with the decrease in stream flow. It is likely that the rapid increase in Mn stream water concentrations during storm events arise from flushing the soil water from the upper soil horizons. ${ }^{8}$ Following this initial peak, the Mn concentration response to subsequent hydrograph peaks is muted until after the next dry period, indicating the importance the antecedent condition exerts on the leaching of the soil water to the stream. In general, the 7-hourly sampling interval does provide a peak associated with the storm event, although we miss the detail associated with the rising limb of the hydrograph. In terms of stream dynamics linked to flow, the greatest changes occur for the Lower Hafren and this may well link to the more rapid transit from the forest ditch systems that rapidly convey water during storm periods, which in turn may link to flushing of throughfall and stemflow. Set against this, the high dampening of rainfall signals even for relatively inert elements implies long and variable residence times. ${ }^{34-37}$ Rather, we would consider that localised inputs may be significant as for example high Mn concentrations have been observed at one groundwater site within the gravels near to the river (VB1). In contrast, the diurnal patterns are most clearly observed for the Upper Hafren (Figure 6) and this may be linked to higher light levels associated with the moorland as opposed to the forest areas.

Further, during very low-flow periods $\left(0.018 \mathrm{~m}^{3} \mathrm{~s}^{-1}\right.$ for the Upper Hafren; $0.032 \mathrm{~m}^{3} \mathrm{~s}^{-1}$ for the Lower Hafren) that occur during the lower rainfall periods (March to September), diurnal oscillations can be observed for both the Upper Hafren and Lower Hafren when Mn concentrations are minimal in mid-afternoon and peak around midnight (Figure 6). A case study is presented of a storm period and the subsequent return to baseflow conditions for the Upper Hafren stream draining from the open moorland. Following a 20-day dry period up to day 112, there was $55 \mathrm{~mm}$ precipitation for 2 days with a rise in the stream Mn concentration from 12 to $24 \mu \mathrm{g} \mathrm{L}^{-1}$ (Figure 7). Without further rainfall events between days 115 and 125, the stream flow declined with diurnal cycling of $\mathrm{Mn}$ resuming on day 117 . The initial cycle amplitude of $1 \mu \mathrm{g} \mathrm{L}^{-1}$ gradually increased to 2.7 $\mu \mathrm{g} \mathrm{L}{ }^{-1}$ on day 125 (30\% of the mean Mn concentration of $\left.9.4 \mu \mathrm{g} \mathrm{L}^{-1}\right)$. For samples 
collected from the Lower Hafren site (Figure 6) in the forest the same pattern is observed

363 as at the moorland Upper Hafren site, with a slightly smaller amplitude of $2 \mu \mathrm{g} \mathrm{L}{ }^{-1}$ which

364 represents $16 \%$ of the mean $\mathrm{Mn}$ concentration of $12 \mu \mathrm{g} \mathrm{L}^{-1}$; i.e., it appears that the

365 shading from the forest has reduced the amplitude of the diurnal cycle. The percentage

366 amplitude of the cycle in the stream at Plynlimon is much smaller than at neutral-alkaline

367 former mining area sites in Montana and Idaho which ranged from $22 \%$ up to $294 \%$ of

368 the mean Mn concentration. ${ }^{38}$ There is no clear evidence that the cycling is related to

369 evapo-transpiration as the stream flow declines steadily throughout the whole period

370 when diurnal cycling is observed. However there is synchronicity of the diurnal $\mathrm{Mn}$

371 cycling with $\mathrm{pH}$, calcium and nitrate; for example $\mathrm{pH}$ rises from a minimum in mid-

372 afternoon of 6.39 to a maximum of 6.51 in the early hours of the morning. We note that

373 with sample storage there may well have been some $\mathrm{CO}_{2}$ degassing and hence there may

374 be some error in the $\mathrm{pH}$ measurement. However, a previous study indicated that the

375 waters are relatively close to saturation with respect to $\mathrm{CO}_{2}$ and hence this error is

376 probably of second order importance. ${ }^{39}$

378 These diurnal changes may well link to 1) biological processing within the stream during

379 the summer months when biological activity will be high and flows very low; 2) light

380 induced oxidation and precipitation / removal of $\mathrm{MnO}_{\mathrm{x}}$ from the water column, and the

381 rate of oxidative loss of $\mathrm{Mn}$ is enhanced due to photosynthesis of the algae ${ }^{40}$ and

382 increases as a function of $\left[\mathrm{OH}^{-}\right]$, however our measurements indicate the loss of $\mathrm{Mn}$ in

383 the daytime is associated with an increase in $\left[\mathrm{H}^{+}\right]$; 3) precipitation / adsorption onto the

384 stream bedrock; 4) absorption by biofilms, and the increase during the dark hours is

385 driven by Mn reduction and dissolution; 5) diurnal fluctuations in groundwaters with

386 more groundwater input at night. At present we are unable to distinguish which is the

387 most important driver or whether it is a combination of two or more of the above

388 mechanisms contributing to the clear diurnal patterns in the Mn stream concentrations at

389 observed during periods of low flow. In contrast to Mn, we observe that arsenic and

390 molybdenum, present in the anionic forms, exhibit the highest concentrations in the

391 diurnal cycle in the early afternoon. ${ }^{27}$ 


\section{3.6 How often do you need to sample to understand the dynamics of Mn cycling in}

394 the stream?

396 Sampling at the high frequency of 7-hourly intervals is attractive as it has offered us the 397 opportunity to gain a better understanding of the processes occurring during storms, and

398 drought, and we can use this data to simulate sampling of lower frequencies (Figure 4).

399 While lower resolution sampling that is typical of standard monitoring programmes

400 (fortnightly to monthly) picks up dips in Mn at extreme low flow, it is only at the weekly

401 scale that greater dynamics start to emerge, but at 7 hourly monitoring a much greater

402 dynamic is revealed. Note that daily sampling shows a similar feature, but of course

403 diurnal patterns cannot be picked up.

404

405

\section{Conclusions}

407

408 Monitoring of $\mathrm{Mn}$ in the headwater streams of the Severn over the last 30 years reveals

409 relatively low levels in relation to the threshold limits established for drinking water. In

410 contrast, the levels in the groundwaters are much higher and would be unsuitable for

411 drinking water use. Generally $\mathrm{Mn}$ is flushed into streams at the onset of significant

412 precipitation events and concentrations increase in response to felling activities, with

413 decay during subsequent years. High resolution monitoring reveals a wealth of dynamic

414 features not picked up with standard monitoring programmes. The mechanisms driving

415 these changes cannot be pinned down here. During the summer and in drought periods

416 there is a small diurnal pattern in Mn concentrations with the highest concentrations

417 occurring at night. During events, there may well be a complex array of inputs including

418 groundwater and near surface inputs of variable chemistry, with the rising limb showing

419 distinctive features as localised inputs near to the stream are flushed to the river at times

420 when the flows have not risen sufficiently to dilute their inputs out. These features need

421 further investigation in the context of hyperheic/groundwater transfers and within-river

422 Mn processing. 
424 Thus, in terms of the initial hypothesis is justified in that undertaking long-term and high

425 intensity monitoring of Mn reveals features not observed within shorter term research

426 programmes. This feature is now being shown to be general for a very wide range of

427 elements. ${ }^{16,27}$ Nonetheless, as long-term and high resolution monitoring information

428 becomes more available, new questions arise linking to issues of within-catchment

429 complexity, long-term climatic and pollution change and the nature of within-river and

430 hyperheic influences river water quality. The key to further understanding probably

431 comes with combining detailed within catchment studies with long-term monitoring

432 programmes within the context of earth observatories and universally available long-term

433 datasets. ${ }^{16,41-43}$

434

\section{Acknowledgements}

436

437 The paper represents a lifetimes study for Colin Neal and Brian Reynolds. During this

438 time so many scientist have contributed with the field work and the chemical analysis.

439 We thank them all. We also acknowledge the contribution from the Journal's reviewers,

440 who contributed significantly to the final version of the paper. 


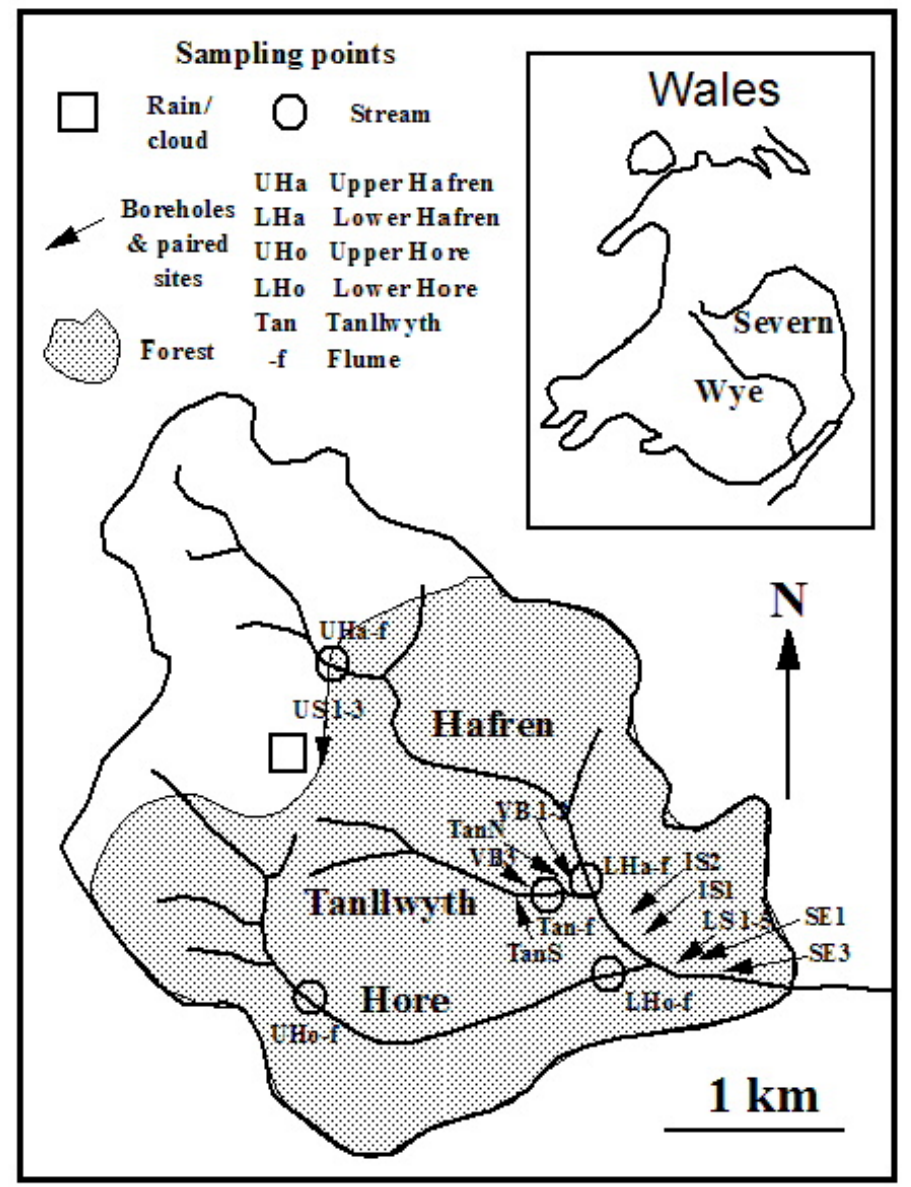


443 Figure 1. Map showing the locations of the streams and groundwater sampling points at 444 Plynlimon. 


\section{Upper Hore}

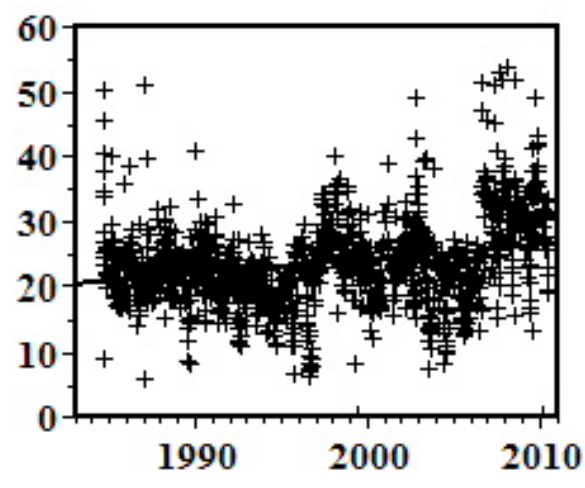

\section{Lower Hore}

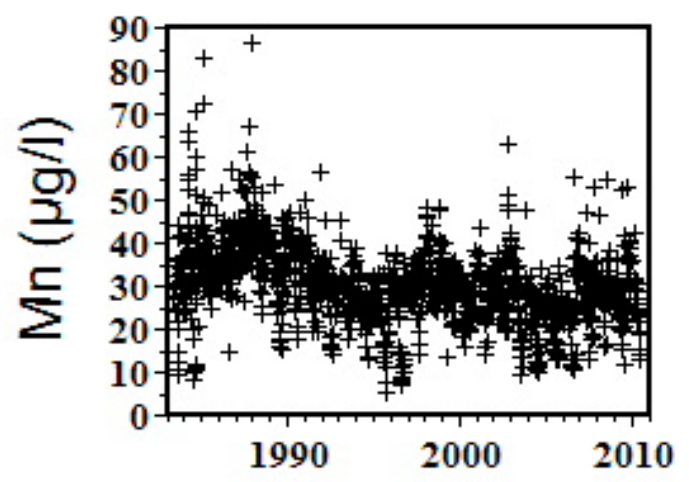

Tanllwyth

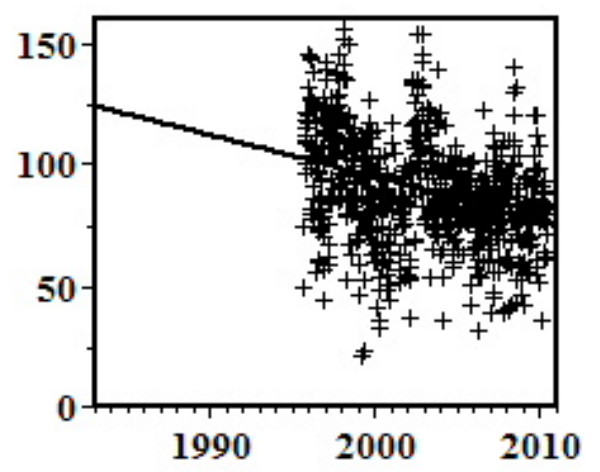

Upper Hafren

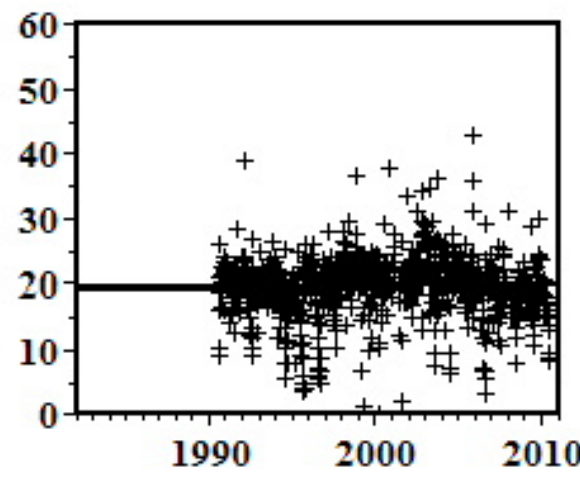

Lower Hafren

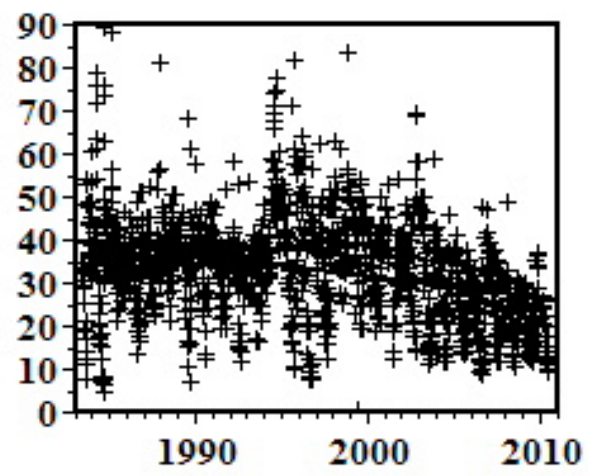

South2Hore

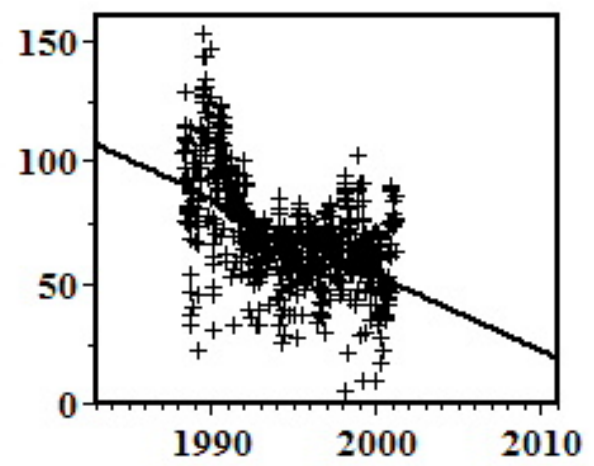

Year 
446 Figure 2. Time series plots of Mn for the monitored streams in the Upper Severn based 447 on weekly monitoring. Linear regression lines are included and the regression statistics 448 are provided in Table 7.

449

450 
Upper Hore

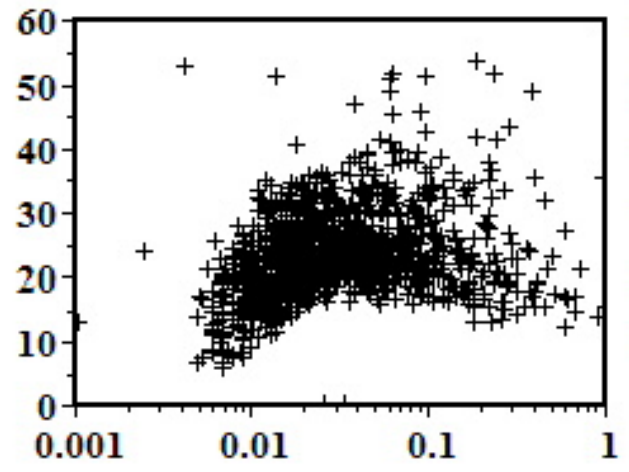

Lower Hore

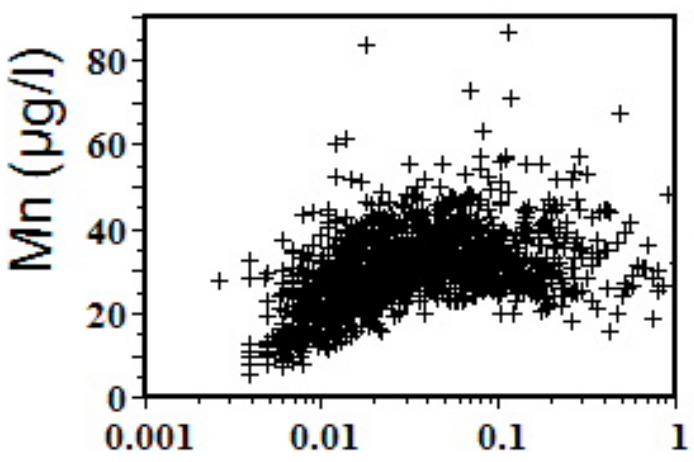

Tanllwyth

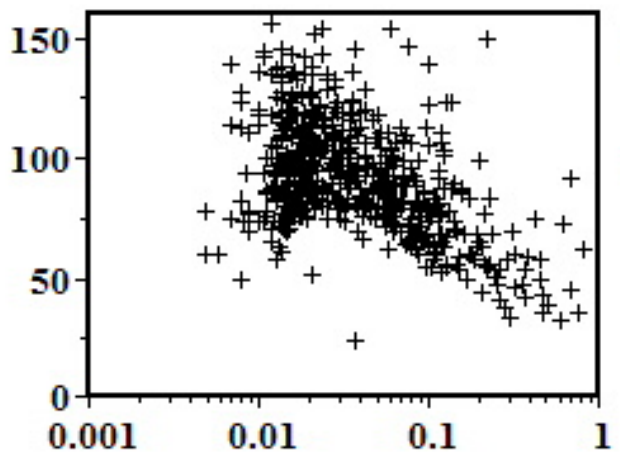

Upper Hafren

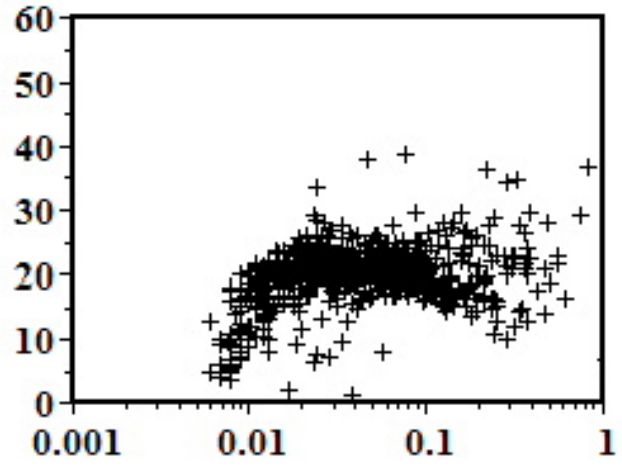

Lower Hafren

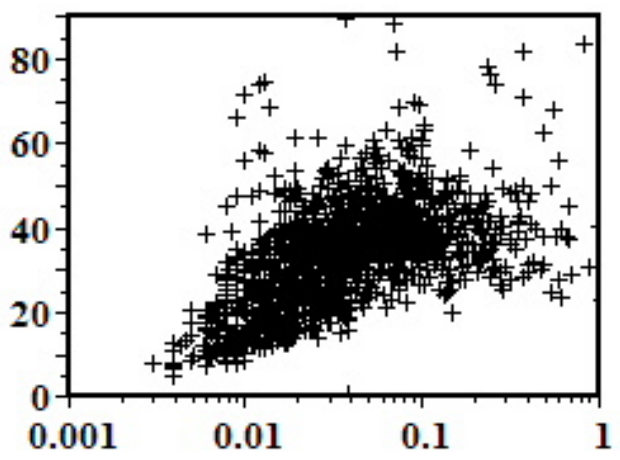

South2Hore

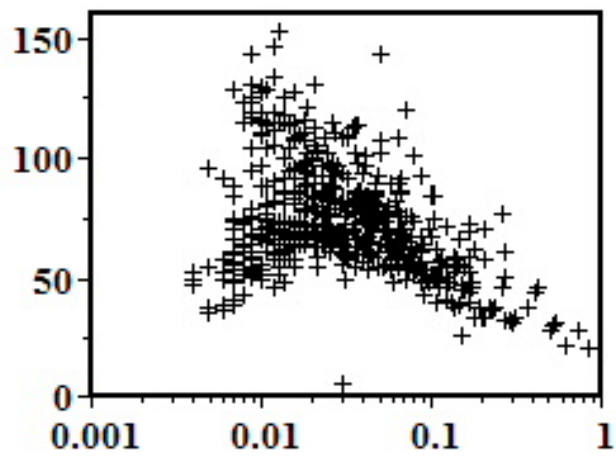

Flow (cumecs) 
452 Figure 3. The relationship between Mn concentration and flow for the Upper Severn 453 streams. Note that there seems to divergent patterns in the plots and linear statistics 454 indicate a mixture of flow and inverse flow relationships with $\mathrm{Mn}$. The statistics are 455 presented in Table 4.

456

457

458

459 
460

Mn: Sampling frequency influences

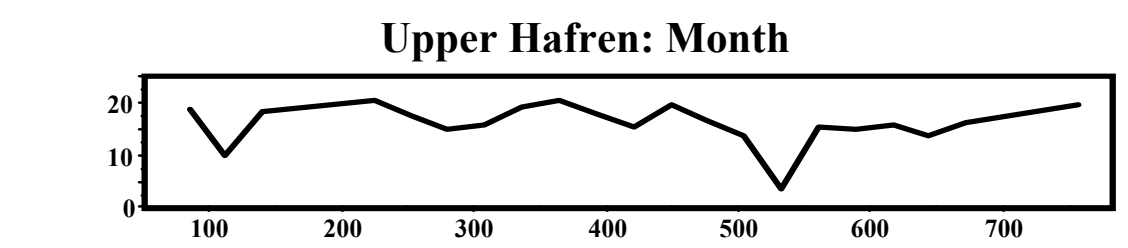

Upper Hafren:Fortnight

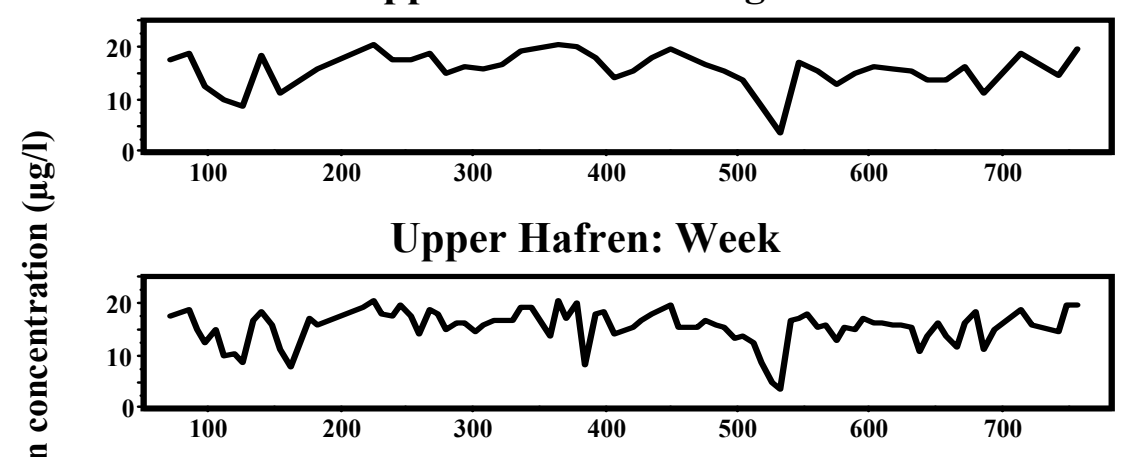

Upper Hafren: 7 hours

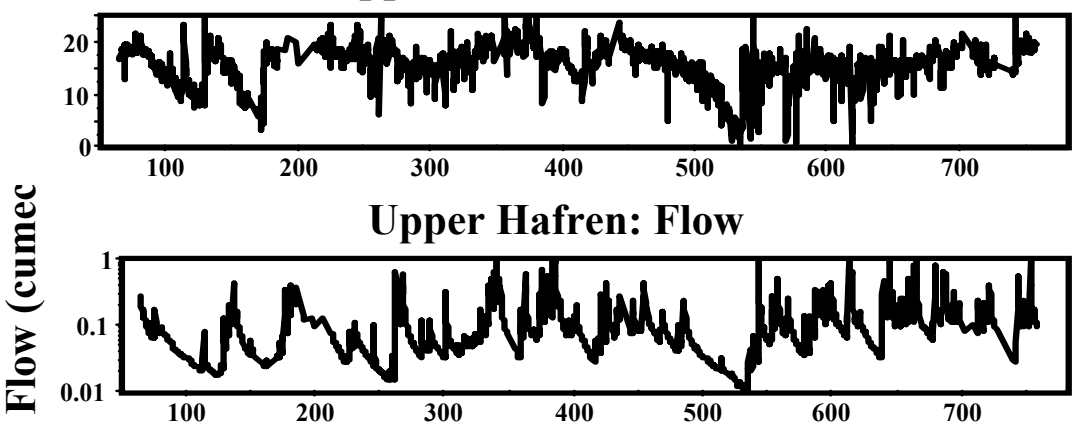

461

Day Number (Day $1=01 / 01 / 2007)$

464 Figure 4. Simulated samplings at different frequencies derived from the 7-hourly 465 samplings.

466 


\section{Upper Hafren}
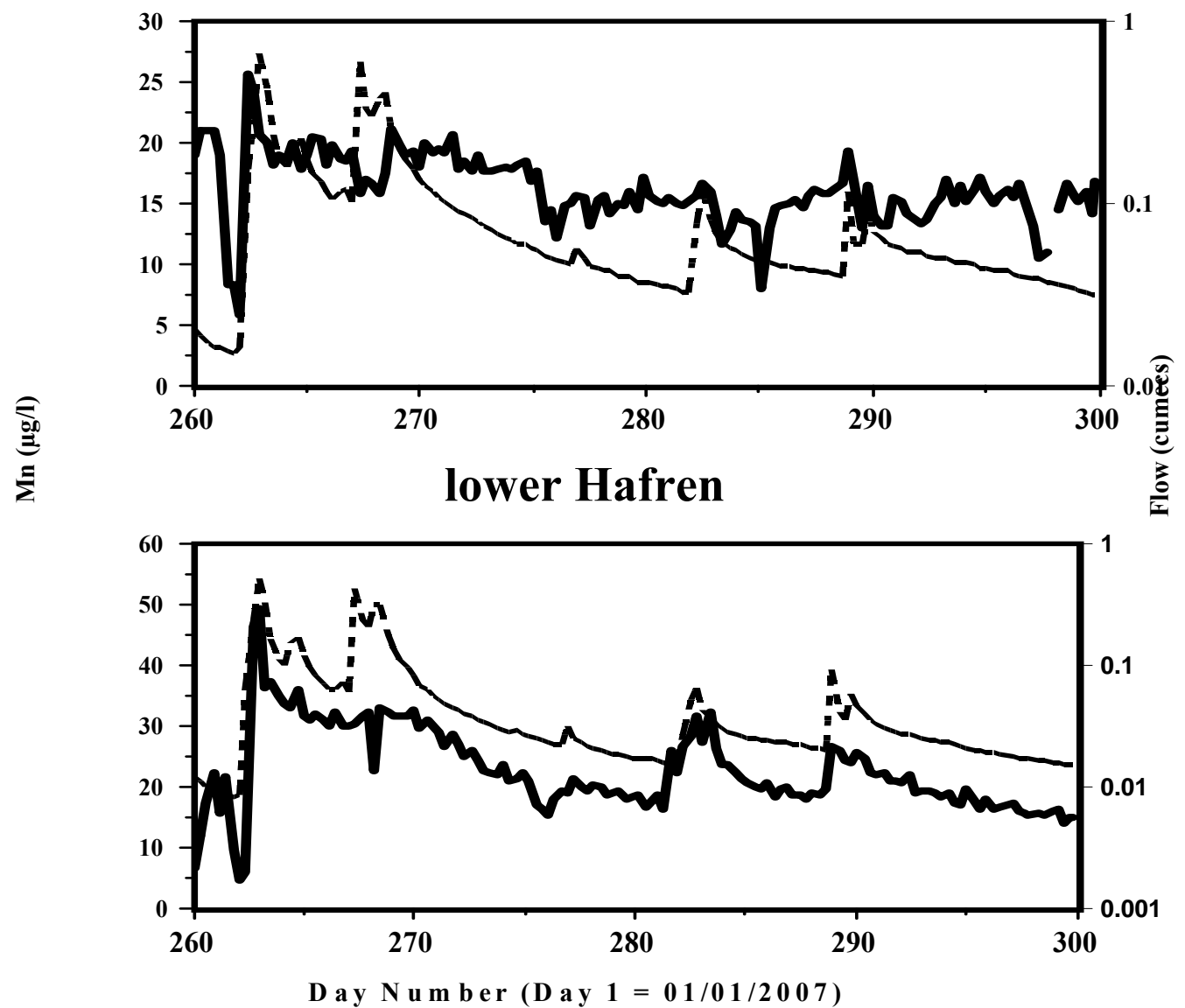

468

469

470 Figure 5. Time series plots of Mn concentration and flow for the Upper and Lower

471 Hafren based on 7 hourly monitoring from $18^{\text {th }}$ September 2007 to $27^{\text {th }}$ October 2007.

472

473 
Upper Hafren

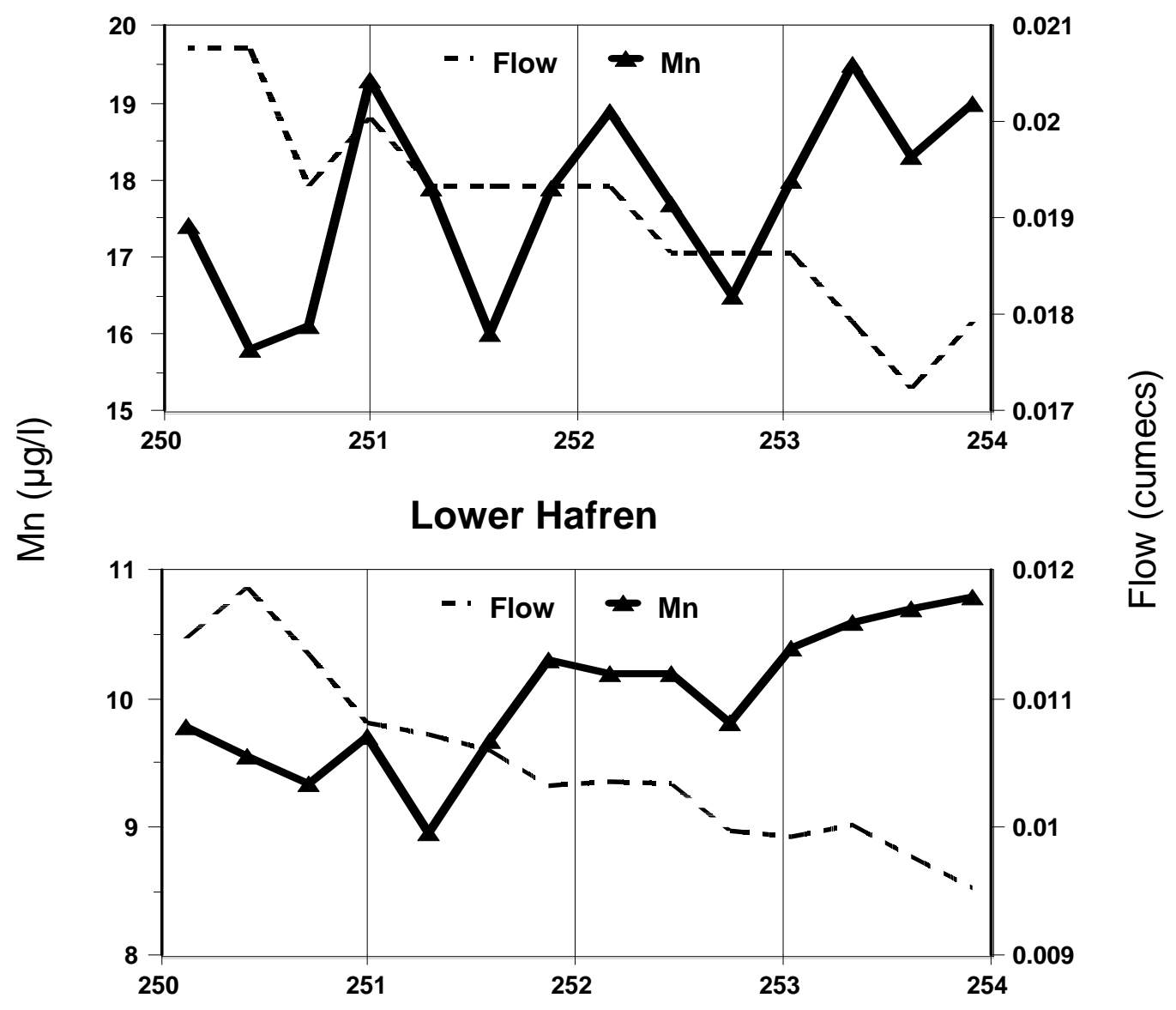

479 Figure 6. Diurnal cycling of manganese for the Upper and Lower Hafren for $3^{\text {rd }}-6^{\text {th }}$ May 4802007 at a time of low and declining flow. 


\section{Upper Hafren}

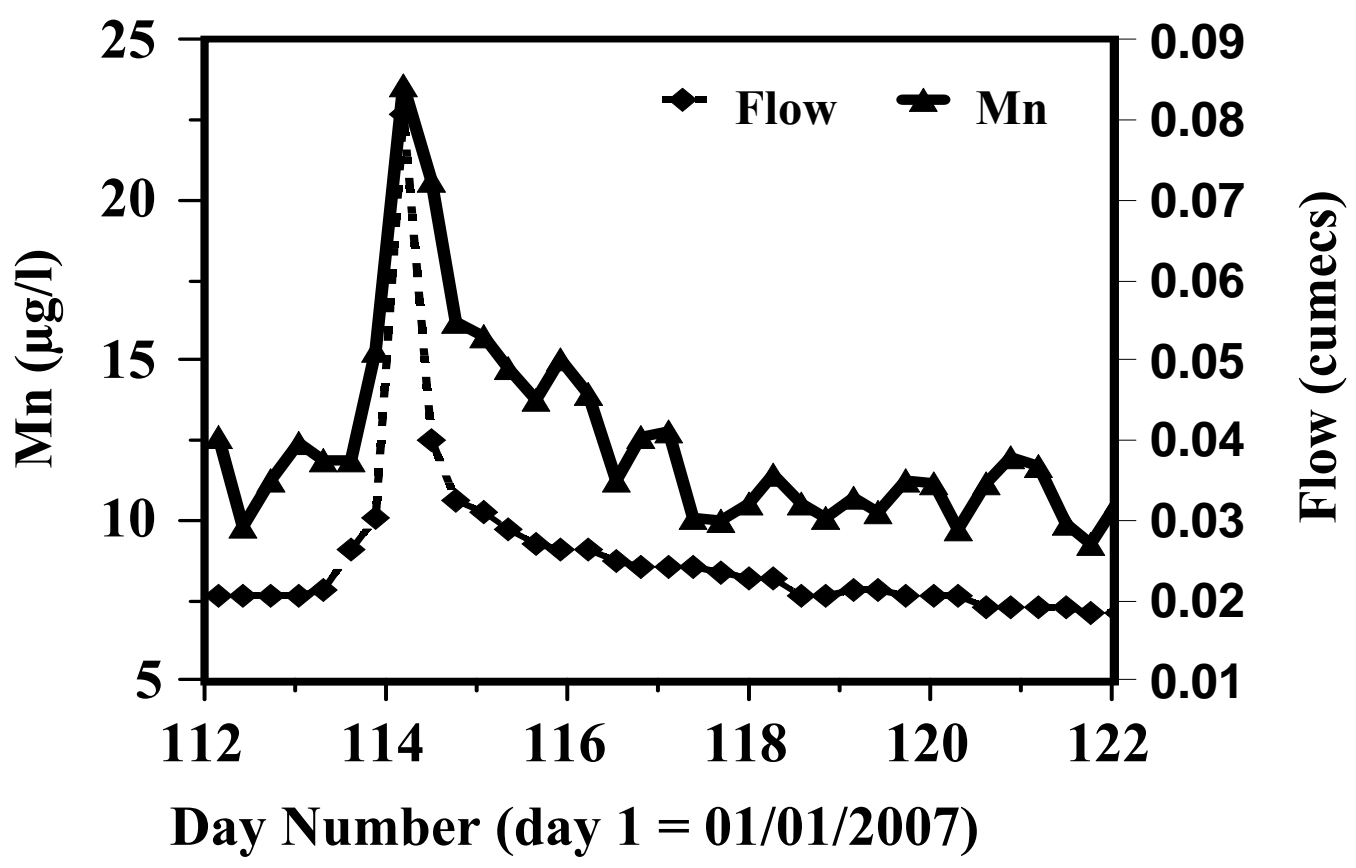

485 Figure 7. Stream Mn concentrations rise during a precipitation event on day $114\left(25^{\text {th }}\right.$

486 April 2007) and then declines and diurnal cycling resumes.

487

488

489 
490

491

492

493

494

495

496

497

498

Table 1. Catchment summary information. The HA4 and LS4 boreholes represent the same site: LS data correspond to a monthly sampling for one year only and the HA4 data include weekly sampling after the first year of sampling. The paired sites have control and felled catchments, the site names have suffix "c" for the control and suffix " $\mathrm{f}$ " for felled sites. SS=Sitka Spruce; M=Acid Grassland. Soil type (Soil) G=Gley; P=Podzol; $\mathrm{Pe}=$ Peat, $\mathrm{Gr}=$ Gravel. Under felling activity $\mathrm{Y}=\mathrm{Yes}, 100 \%$ fell unless indicated otherwise; $\mathrm{N}=$ No fell. The superscript denote felling date: 1, LHa, ongoing thinning; 2, UHo clearfell 2006; 3, LHo, March 1985 to October 1988; 4, Tan, February 1996; 5, S2Ho, August-October 1989; 6, SE1, September-October 1995.

\begin{tabular}{|c|c|c|c|c|c|c|c|}
\hline Site & Area (Ha) & $\begin{array}{c}\text { Soil } \\
\text { Type }\end{array}$ & Veg. Type & Felling Activity & $\begin{array}{c}\text { Sampling } \\
\text { Times/yr }\end{array}$ & Start date & End date \\
\hline \multicolumn{8}{|c|}{ Atmospheric inputs } \\
\hline Rain & - & - & - & - & 52 & $10 / 05 / 83$ & Cont \\
\hline Rain & - & - & - & - & 52 & $08 / 03 / 07$ & $21 / 01 / 09$ \\
\hline Mist & - & - & - & - & 52 & $25 / 9 / 90$ & Cont \\
\hline Throughfall & - & - & - & - & 52 & $01 / 02 / 84$ & $02 / 09 / 92$ \\
\hline Stemflow & - & - & - & - & 52 & $01 / 02 / 84$ & $02 / 09 / 92$ \\
\hline \multicolumn{8}{|c|}{ Main streams } \\
\hline U Hafren & 117 & $\mathrm{Pe}$ & $\bar{M}$ & $\mathrm{~N}$ & 52 & $17 / 07 / 90$ & Cont \\
\hline U Hafren & 117 & $\mathrm{Pe}$ & $\mathrm{M}$ & $\mathrm{N}$ & 1248 & $08 / 03 / 07$ & $21 / 01 / 09$ \\
\hline L Hafren & 347 & $\mathrm{P} / \mathrm{G}$ & $\mathrm{SS}$ & $\mathrm{Y}<25 \%{ }^{1}$ & 52 & $10 / 05 / 83$ & Cont \\
\hline L Hafren & 347 & $\mathrm{P} / \mathrm{G}$ & SS & $\mathrm{Y}<25 \%{ }^{\mathrm{T}}$ & 1248 & $08 / 03 / 07$ & $11 / 03 / 08$ \\
\hline U Hore & 178 & $\mathrm{P} / \mathrm{G}$ & SS & Y $50 \%{ }^{2}$ & & $28 / 08 / 84$ & Cont \\
\hline L Hore & 335 & $\mathrm{P} / \mathrm{G}$ & SS & Y $50 \%{ }^{3}$ & 52 & $10 / 05 / 83$ & Cont \\
\hline \multicolumn{8}{|c|}{ Intermediate size stream } \\
\hline Tanllwyth & 51 & $\mathrm{G}$ & SS & Y $50 \%{ }^{4}$ & 52 & $17 / 09 / 91$ & Cont \\
\hline \multicolumn{8}{|c|}{ Small streams } \\
\hline South2Hore & $3-6$ & $\bar{P}$ & SS & $\mathrm{Y} 100 \%{ }^{5}$ & 52 & $19 / 04 / 88$ & $20 / 02 / 01$ \\
\hline SE1f & $2-4$ & $P$ & SS & Y100\% ${ }^{6}$ & 26 & $20 / 09 / 94$ & $14 / 02 / 01$ \\
\hline SE3c & $2-4$ & $\mathrm{P}$ & SS & $\mathrm{N}$ & 26 & $11 / 10 / 94$ & $\begin{array}{l}27 / 04 / 99 \\
\end{array}$ \\
\hline TanN & $<2$ & $\mathrm{G}$ & SS & $\mathrm{N}$ & 26 & $28 / 04 / 94$ & $27 / 04 / 99$ \\
\hline TanS & $<2$ & $\mathrm{G}$ & SS & Y100\% ${ }^{4}$ & 26 & $28 / 04 / 94$ & $\begin{array}{l}14 / 02 / 01 \\
\end{array}$ \\
\hline \multicolumn{8}{|c|}{ Groundwater } \\
\hline HA4 & & $\mathrm{P}$ & SS & Y100\% ${ }^{6}$ & $12 / 52$ & $24 / 04 / 94$ & $\begin{array}{l}14 / 02 / 01 \\
\end{array}$ \\
\hline SE1 & & $\mathrm{P}$ & SS & $\mathrm{Y} 100 \%{ }^{6}$ & 26 & $10 / 05 / 95$ & $27 / 04 / 99$ \\
\hline SE3 & & $\mathrm{P}$ & SS & $\mathrm{N}$ & 26 & $10 / 05 / 95$ & $27 / 04 / 99$ \\
\hline TanN & & $\mathrm{G}$ & SS & $\mathrm{N}$ & 26 & $05 / 07 / 94$ & $27 / 04 / 99$ \\
\hline TanS & & $\bar{G}$ & SS & Y100\% ${ }^{4}$ & 26 & $09 / 08 / 94$ & $27 / 04 / 99$ \\
\hline US1 & & $\mathrm{Pe}$ & $\mathrm{M}$ & $\mathrm{M}$ & 12 & $24 / 04 / 94$ & $\begin{array}{l}12 / 07 / 95 \\
\end{array}$ \\
\hline US2 & & $\mathrm{P}$ & SS & $\mathrm{N}$ & 12 & $24 / 04 / 94$ & $\begin{array}{l}12 / 07 / 95 \\
\end{array}$ \\
\hline US3 & & $\mathrm{P}$ & SS & $\mathrm{N}$ & 12 & $24 / 04 / 94$ & $14 / 06 / 95$ \\
\hline US4 & & $\mathrm{P}$ & SS & $\mathrm{N}$ & 12 & $24 / 04 / 94$ & $12 / 07 / 95$ \\
\hline LS1 & & $P$ & SS & $\mathrm{N}$ & 12 & $24 / 04 / 94$ & $12 / 07 / 95$ \\
\hline LS2 & & $\mathrm{P}$ & SS & $\mathrm{N}$ & 12 & $24 / 04 / 94$ & $\begin{array}{l}12 / 07 / 95 \\
\end{array}$ \\
\hline LS3 & & $\mathrm{P}$ & SS & $\mathrm{N}$ & 12 & $24 / 04 / 94$ & $\begin{array}{l}12 / 07 / 95 \\
\end{array}$ \\
\hline LS4 & & $P$ & SS & $\mathrm{N}$ & 12 & $24 / 04 / 94$ & $\begin{array}{l}12 / 07 / 95 \\
\end{array}$ \\
\hline IS1 & & $\mathrm{P}$ & SS & $\mathrm{N}$ & 12 & $24 / 04 / 94$ & $\begin{array}{l}12 / 07 / 95 \\
\end{array}$ \\
\hline IS2 & & $\mathrm{P}$ & SS & $\mathrm{N}$ & 12 & $24 / 04 / 94$ & $\begin{array}{l}12 / 07 / 95 \\
\end{array}$ \\
\hline VB1 & & $\mathrm{P} / \mathrm{Gr}$ & $\mathrm{M}$ & $\mathrm{M}$ & 12 & $24 / 04 / 94$ & $12 / 07 / 95$ \\
\hline
\end{tabular}


500 Table 2. Summary statistics for manganese concentrations $\left(\mu \mathrm{g} \mathrm{L}^{-1}\right)$ in rainfall, cloud 501 water, stream water and groundwater for the Upper Severn catchment. The low and high 502 refer to dry and wet conditions with the average for the bottom and top $10 \%$ of flows / 503 volume of catch / groundwater level.

Average Fw Avg Median std $\min \max \mathrm{N}$ Low High Atmospheric inputs

\section{Rainfall \\ Cloud}

Throughfall

Stemflow

U Hafren
L Hafren
U Hore
L Hore

Tanllwyth

South 2 Hore

SE1

SE3

TanN

TanS

US1

US2

US3

LS1

LS2

LS3

LS4

IS1

IS1

SE1

SE3

TanN

TanS

Quarry

VB1

$\begin{array}{ccccccccc}2 & 1 & 1 & 5 & 0 & 99 & 1023 & 8 & 0 \\ 26 & 32 & 8 & 82 & 0 & 1130 & 831 & 51 & 5 \\ 723 & 1250 & 571 & 862 & 61 & 9160 & 141 & 1566 & 652 \\ 1414 & 681 & 949 & 1640 & 72 & 10900 & 133 & 1839 & 1005\end{array}$

Main streams

$\begin{array}{lcccccccc}20 & 20 & 20 & 5 & 0 & 43 & 1000 & 11 & 18 \\ 34 & 40 & 34 & 13 & 5 & 128 & 1434 & 22 & 45 \\ 24 & 22 & 23 & 7 & 6 & 90 & 1324 & 17 & 21 \\ 31 & 33 & 30 & 9 & 6 & 87 & 1434 & 21 & 35\end{array}$

Intermediate stream

$\begin{array}{lllllllll}89 & 75 & 87 & 23 & 22 & 167 & 735 & 107 & 60\end{array}$

Small streams

$\begin{array}{cccccccc}55 & 68 & 22 & 10 & 153 & 638 & 61 & 44 \\ 14 & 5 & 9 & 1 & 67 & 173 & 4 & 19 \\ 85 & 25 & 40 & 3 & 195 & 124 & 14 & 121 \\ 11 & 13 & 12 & 1 & 79 & 106 & 37 & 11 \\ 9 & 11 & 8 & 2 & 68 & 152 & 11 & 8\end{array}$

Groundwater

$\begin{array}{cccccccc}\text { na } & 62 & 20 & 20 & 103 & 16 & \text { na } & \text { na } \\ \text { na } & 48 & 54 & 33 & 233 & 15 & \text { na } & \text { na } \\ \text { na } & 41 & 16 & 16 & 100 & 16 & \text { na } & \text { na } \\ \text { na } & 51 & 9 & 9 & 74 & 16 & \text { na } & \text { na } \\ \text { na } & 129 & 66 & 40 & 261 & 15 & \text { na } & \text { na } \\ \text { na } & 27 & 146 & 21 & 663 & 16 & \text { na } & \text { na } \\ \text { na } & 41 & 53 & 27 & 325 & 206 & 118 & 40 \\ \text { na } & 23 & 79 & 16 & 367 & 16 & \text { na } & \text { na } \\ \text { na } & 47 & 91 & 16 & 367 & 32 & \text { na } & \text { na } \\ \text { na } & 149 & 58 & 28 & 362 & 102 & 168 & 160 \\ \text { na } & 132 & 46 & 8 & 230 & 102 & 82 & 150 \\ \text { na } & 166 & 47 & 47 & 533 & 132 & 410 & 397 \\ \text { na } & 217 & 115 & 67 & 460 & 136 & 218 & 157 \\ \text { na } & 2 & 44 & 0 & 505 & 131 & 3 & 10 \\ \text { na } & 201 & 234 & 133 & 771 & 16 & \text { na } & \text { na }\end{array}$


506 Table 3. Summary statistics for manganese concentrations $\left(\mu \mathrm{g} \mathrm{L}^{-1}\right)$ in rainfall, stream 507 water and groundwater for the Upper Wye and Vyrnwy areas. The low and high refer to 508 dry and wet conditions with the average for the bottom and top $10 \%$ of flows / volume of 509 catch / groundwater level.

$$
\text { Avg Fw Avg Median std min max } \mathrm{N} \text { Low High }
$$

$\begin{array}{cccccccccc}\text { Afon Gwy } & 17 & 16 & 17 & 6 & 0 & 54 & 83 & 15 & 16 \\ \text { Afon Cyff } & 24 & 20 & 22 & 12 & 0 & 93 & 83 & 36 & 20 \\ \text { Nant Iago } & 33 & \text { na } & 34 & 8 & 8 & 45 & 20 & \text { na } & \text { na } \\ \text { Rainfall } & 7 & \text { na } & 12 & 12 & 0 & 97 & 126 & \text { na } & \text { na } \\ \text { Stream 1 } & 10 & \text { na } & 6 & 11 & 0 & 74 & 151 & \text { na } & \text { na } \\ \text { Stream 2 } & 7 & \text { na } & 3 & 17 & 0 & 180 & 160 & \text { na } & \text { na } \\ \text { Borehole 1 } & 18 & \text { na } & 5 & 48 & 1 & 281 & 162 & \text { na } & \text { na } \\ \text { Borehole 2 } & 3 & \text { na } & 2 & 10 & 0 & 90 & 163 & \text { na } & \text { na }\end{array}$

513 Table 4. Multiple linear regression of Mn versus flow and 1/flow for the monitored

514 streams in the Upper Severn based on weekly monitoring (see Figure 3).

\begin{tabular}{|c|c|c|c|c|c|c|c|c|c|}
\hline & Flow & $2 \sigma$ & 1/Flow & $2 \sigma$ & Constant & $2 \sigma$ & $\mathbf{r}^{2}$ & $\mathbf{N}$ & p \\
\hline Upper Hafren & -7.69 & 1.95 & -0.1 & 0.01 & 22.91 & 7.79 & 0.274 & 998 & $<0.0001$ \\
\hline Upper Hore & -6.81 & 1.78 & -0.17 & 0.02 & 28.39 & 12.25 & 0.177 & 1218 & $<0.0001$ \\
\hline Lower Hafren & 0.73 & 1.44 & -0.67 & 0.06 & 40.79 & 21.41 & 0.299 & 1409 & $<0.0001$ \\
\hline Lower Hore & -1.85 & 1.03 & -0.39 & 0.03 & 36.44 & 15.39 & 0.279 & 1410 & $<0.0001$ \\
\hline Tanllwyth & -33.17 & 12.91 & 0.52 & 0.07 & 88.76 & 48.86 & 0.459 & 392 & $<0.0001$ \\
\hline South2Hore & -36.55 & 7.87 & 0.15 & 0.09 & 71.28 & 39.95 & 0.188 & 637 & $<0.0001$ \\
\hline
\end{tabular}


Table 5. Total Mn concentrations measured in bedrock at Plynlimon. ${ }^{31,32}$

\begin{tabular}{|l|l|l|l|l|}
\hline Rock type & Age & Mean $\left(\mathrm{mg} \mathrm{kg}^{-1}\right)$ & Std dev $\left(\mathrm{mg} \mathrm{kg}^{-1}\right)$ & $\mathrm{N}$ \\
\hline Devils Bridge Formation & Silurian & 3200 & 906 & 4 \\
\hline Cwmere Group & Silurian & 383 & 126 & 8 \\
\hline Brynglas Group & Ordovician & 525 & 115 & 8 \\
\hline Drosgol Group & Ordovician & 218 & 27.4 & 7 \\
\hline
\end{tabular}

Table 6. Total Mn concentrations measured by DC-arc direct reading emission spectrometry in a ferric stagnopodzol soil located on the Devils Bridge Formation in the Wye catchment at

523 Plynlimon (CEH / BGS unpublished data). ${ }^{33}$

\begin{tabular}{|l|l|l|}
\hline Horizon & Thickness $(\mathrm{cm})$ & $\mathrm{Mn}\left(\mathrm{mg} \mathrm{kg}^{-1}\right)$ \\
\hline Oh & 10 & 60 \\
\hline Eag & 7 & 40 \\
\hline Bs1 & 30 & 270 \\
\hline Bs2 & 14 & 840 \\
\hline Bs/C & 9 & 1070 \\
\hline C & $30+$ & 1500 \\
\hline
\end{tabular}

Table 7. Linear regression of Mn versus time for the monitored streams in the Upper

527 Severn based on weekly monitoring (see Figure 2).

$\begin{array}{lccccccc} & \text { Gradient } & 2 \sigma & \text { Constant } & 2 \sigma & \mathbf{r}^{2} & \mathbf{N} & \mathbf{p} \\ \text { Upper Hafren } & 0.23 & 0.05 & -441.2 & 12.9 & 0.069 & 1324 & <0.0001 \\ \text { Upper Hore } & 0.01 & 0.05 & -1.2 & 9.1 & 0.000 & 1000 & \\ \text { Lower Hafren } & -0.49 & 0.08 & 1011.7 & 24.3 & 0.093 & 1420 & <0.0001 \\ \text { Lower Hore } & -0.41 & 0.06 & 842.9 & 16.9 & 0.128 & 1423 & <0.0001 \\ \text { Tanllwyth } & -1.81 & 0.31 & 3712.3 & 53.3 & 0.110 & 1127 & <0.0001 \\ \text { South2Hore } & -3.10 & 0.40 & 6248.5 & 37.7 & 0.275 & 638 & <0.0001\end{array}$




\section{References}

532 1. M. Hornung, K. R. Bull, M. Cresser, J. Ullyett, J. R. Hall, S. Langan, P. J.

533 Loveland and M. J. Wilson, Envir. Pollut., 1995, 87, 207-214.

534 2. J. A. Hudson, K. Gilham and I. Calder, Hydrol. Earth Syst. Sci., 1997, 1, 207-214.

535 3. C. Neal, S. J. Ormerod, S. J. Langan, T. R. Nisbet and J. Roberts, Hydrol. Earth

$536 \quad$ Syst. Sci., 2004, 8, 589-595.

537 4. C. B. Buckley and L. Keil, in Acid Waters in Wales eds. R. Edwards, A. Gee and

538 J. Stoner, Kluwer Dordrecht, Editon edn., 1990, pp. 145-158.

$539 \quad$ 5. K. V. Heal, Sci. Total Environ., 2001, 265, 169-179.

$540 \quad$ 6. $\quad$ A. M. Hardie, K. V. Heal and A. Lilly, Water Air Soil Pollut., 2007, 182, 369-

541382.

542 7. K. V. Heal, P. E. Kneale and A. T. Macdonald, J. Hydrol. Sci., 2002, 47, 769-780.

543 8. C. Abesser, R. Robinson and C. Soulsby, J. Hydrol., 2006, 326, 59-78.

544 9. S. C. Homoncik, A. M. MacDonald, K. V. Heal, B. E. O. Dochartaigh and B. T.

545 Ngwenya, Sci. Total Environ., 2010, 408, 2467-2473.

$546 \quad$ 10. Forestry \& Water Guidelines, Forestry Commission, Edinburgh, 2003.

547 11. K. J. Sly, M. C. Hodgkinson and V. Arunpairojana, Applied Environmental

$548 \quad$ Microbiology, 1990, 56, 628-639.

549 12. N. N. Greenwood and A. Earnshaw, Chemistry of the Elements, Elsevier,

$550 \quad$ Amsterdam, 2005.

$551 \quad$ 13. C. Neal, Hydrol. Earth Syst. Sci., 2000, 4, 499-509.

552 14. C. Neal, R. J. Wilkinson, M. Neal, M. L. Harrow, H. Wickham, L. Hill and C.

$553 \quad$ Morfitt, Hydrol. Earth Syst. Sci., 1997, 1, 583-618.

554 15. C. Neal, A. J. Robson, P. Shand, W. M. Edmunds, A. J. Dixon, D. K. Buckley, S. Hill, M. L. Harrow, M. Neal and B. Reynolds, Hydrol. Earth Syst. Sci., 1997, 1, 3-18.

16. C. Neal, B. Reynolds, P. Rowland, D. Norris, J. W. Kirchner, M. Neal, D. Sleep, A. Lawlor, C. Woods, S. Thacker, H. Guyatt, C. Vincent, K. Hockenhull, H. Wickham, S. Harman and L. Armstrong, Sci. Total Environ., 2011, in press.

17. J. W. Kirchner, X. Feng, C. Neal and A. J. Robson, Hydrol. Process., 2004, 18, 1353-1359.

18. C. Brandt, M. Robinson and J. W. Finch, Hydrol. Earth Syst. Sci., 2004, 8, 345354.

19. C. Neal, B. Reynolds, M. Neal, B. Pugh and H. Wickham, Hydrol. Earth Syst. Sci., 2001, 5, 459-476.

20. C. Neal, Hydrol. Earth Syst. Sci., 1997, 1, 381-764.

21. J. A. Hudson, S. B. Crane and J. R. Blackie, Hydrol. Earth Syst. Sci., 1997, 1, 409-427.

22. J. Wilkinson, B. Reynolds, C. Neal, S. Hill, M. Neal and M. Harrow, Hydrol. Earth Syst. Sci., 1997, 1, 557-569.

572 24. C. Neal, G. P. Ryland, T. Conway, H. A. Jeffery, M. Neal, A. J. Robson, C. J. 
25. M. Niklinska, M. Maryanski, G. Szarek and R. Laskowski, Water Air Soil Pollut., 1995, 85, 1771-1776.

26. R. J. Skrivan, J. Rusek, D. Fottova, M. Burian and L. Minarik, Water Air Soil Pollut., 1995, 85, 841-846.

27. A. P. Rowland, C. Neal, B. Reynolds, H. P. Jarvie, D. Sleep, A. J. Lawlor and M. Neal, J. Environ. Monit., 2011, 13, 1255-1263.

28. B. Reynolds, C. Neal., M. Hornung and P. A. Stevens, J. Hydrol., 1986, 87, 167185.

29. C. Neal, B. Reynolds, M. Neal and B. Williams, Hydrol. Earth Syst. Sci., 2004, 8, 460-484.

30. P. Durand, C. Neal, H. A. Jeffery, G. P. Ryland and M. Neal, J. Hydrol., 1994, 157, 139-156.

31. N. Breward, University of Leeds Unpublished, 1990.

32. N. Breward, Geochemical cycling in the Wye catchment. Part 1. Geochemical relationships in the bedrock and stream sediments of the Cyff system. Report No. 85/11, 1985.

33. D. Peachey and N. Breward, A comparative study of the results obtained from the analysis of geological samples by various methods Report No. 62, 1980.

34. J. W. Kirchner, X. Feng and C. Neal, Nature, 2000, 403, 524-527.

35. J. W. Kirchner, X. Feng and C. Neal, J. Hydrol., 2001, 254, 81-100.

36. C. Neal and J. W. Kirchner, Hydrol. Earth Syst. Sci., 2000, 4, 295-310.

37. S. E. Godsey, W. Aas, T. A. Clair, H. A. de Wit, I. J. Fernandez, J. S. Kahl, I. A. Malcolm, C. Neal, M. Neal, S. J. Nelson, S. A. Norton, M. C. Palucis, B. L.

Skjelkv ${ }^{\circ}$ ale, S. Soulsby, D. Tetzlaff and J. W. Kirchner, Hydrol. Process., 2010, 24, 1660-1671.

38. D. A. Nimick, C. H. Gammons, T. E. Cleasby, J. P. Madison, D. Skaar and C. M. Brick, Water Resour. Res., 2003, 39, 1247.

39. C. Neal, Sci. Total Environ., 1988, 76, 279-283.

40. D. T. Scott, D. M. McKnight, B. M. Voelker and D. C. Hrncir, Environ. Sci. Technol., 2002, 36, 453-459.

41. C. Neal, P. Rowland, P. Scholefield, C. Vincent and D. Woods, Sci. Total Environ., 2011, 409, 1516-1529.

42. C. Neal, B. Reynolds, D. Norris, J. W. Kirchner, M. Neal, P. Rowland, H. Wickham, S. Harman, L. Armstrong, D. Sleep, A. Lawlor, C. Woods, B. Williams, M. Fry, G. Newton and D. Wright, Hydrol. Process. (HP Today), 2011, DOI: 10.1002/hyp.8191.

43. C. Neal, M. Bowes, H. P. Jarvie, P. Scholefield, G. J. L. Leeks, M. Neal, P. Rowland, H. Wickham, S. Harman, L. Armstrong, D. Sleep, A. Lawlor and C. E. Davies, Hydrol. Process. (HP Today), 2011, in press. 
Article (refereed) - postprint

Rowland, A.P.; Neal, C.; Reynolds, B.; Neal, M.; Lawlor, A.J.; Sleep, D.. 2012 Manganese in the upper Severn mid-Wales. Journal of Environmental Monitoring, 14 (1). 155-164. 10.1039/c1em10651a

(C) The Royal Society of Chemistry 2012

This version available http://nora.nerc.ac.uk/21141/

NERC has developed NORA to enable users to access research outputs wholly or partially funded by NERC. Copyright and other rights for material on this site are retained by the rights owners. Users should read the terms and conditions of use of this material at http://nora.nerc.ac.uk/policies.html\#access

This document is the author's final manuscript version of the journal article following the peer review process. Some differences between this and the publisher's version may remain. You are advised to consult the publisher's version if you wish to cite from this article.

http://www.rsc.org

\section{Contact CEH NORA team at noraceh@ceh.ac.uk}

